\title{
The Role of Tissue Factor in Thrombosis and Hemostasis
}

\author{
M. A. MALÝ ${ }^{1}$, P. TOMAŠOV ${ }^{1}$, P. HÁJEK ${ }^{1}$, P. BLAŠKO ${ }^{1}$, I. HRACHOVINOVÁ ${ }^{2}$, \\ P. SALAJ ${ }^{2}, J^{\prime}$. VESELKA ${ }^{1}$ \\ ${ }^{1}$ University Hospital Motol, Department of Cardiology and ${ }^{2}$ Institute of Hematology and Blood \\ Transfusion, Prague, Czech Republic
}

Received June 27, 2006

Accepted October 16, 2006

On-line available November 6, 2006

\begin{abstract}
Summary
The tissue factor (TF) is one of the most important regulators of arterial thrombosis. Because arterial thrombosis is the pathophysiologic background of acute coronary syndrome, the possible impact of blocking the arterial thrombosis on its onset is a challenging problem. The investigations of TF brought a new concept of "cell-based coagulation model" which highlighted the question of blood-borne TF as a source of TF in circulating blood. In this review we summarize essential information on the pathophysiology, molecular structure, expression and distribution of TF and we propose a novel concept of blood-borne TF, suggesting the possibilities of inhibition of the coagulation cascade with newly synthetized drugs.
\end{abstract}

\section{Key words}

Tissue factor $\bullet$ Thrombosis $\bullet$ Hemostasis $\bullet$ Coagulation $\bullet$ Microparticles

\section{Introduction}

Tissue factor (TF) is a major regulator of normal hemostasis and thrombosis (Nemerson 1988). TF, which is a membrane-bound molecule, acts as an essential cofactor with activated factor VIIa to form a complex that cleaves factors IX and $\mathrm{X}$ and activates the whole coagulation cascade (Banner et al. 1996). Recent investigations suggest the existence of a blood-borne pool of $\mathrm{TF}$ that may play a critical role in the propagation of thrombosis (Giesen et al. 1999). These investigations revealed that $\mathrm{TF}$ bound to procoagulant microparticles, which are present in the circulating blood under pathophysiological conditions and might exert a specific thrombogenic potential (Nieuwland et al. 1997).
Consequently high levels of shed apoptotic microparticles and TF activity were found in extracts from atherosclerotic plaques (Marmur et al. 1996, Mallat et al. 1999). Increased levels of microparticles with a procoagulant potential were found in the peripheral circulating blood of patients with acute coronary syndrome (ACS) (Mallat et al. 2000).

\section{Pathophysiology}

TF (also known as coagulation factor III or tissue thromboplastin) is a transmembrane glycoprotein responsible for the onset of blood coagulation. The classical view of blood coagulation as a cascade of activated coagulation factors consists of intrinsic and extrinsic pathways. After vascular injury, TF, like the 
serine protease receptor for the coagulation factor VIIa (FVIIa), binds circulating FVII which then turns by allosteric activation into an activated form FVIIa. Besides this activation, TF enhances proteolytic and amidolytic activity of FVIIa and TF/FVIIa complex, which subsequently turns factor $\mathrm{X}(\mathrm{FX})$ into FXa. FXa as a prothrombinase complex (FXa/FVa) cleaves prothrombin into thrombin and thrombin then cleaves fibrinogen into fibrin, completing the extrinsic pathway of blood coagulation. TF/FVIIa complex is also capable of turning zymogens FVII and at slower rate also factor IX (FIX) into their active forms FVIIa and FIXa (Ruf 1998). FIXa together with its cofactor VIIIa (FVIIIa) activate FX into FXa, thus explaining the role of $\mathrm{TF}$ in the intrinsic pathway of blood coagulation. Factor $\mathrm{V}(\mathrm{FV})$ and factor VIII (FVIII) are transformed into their active forms by thrombin, thus providing a back-activation loop.

At present, blood coagulation is evolving into more complex aspects uniting the whole process and emphasizing the role of cells and activated platelets. A cell-based model involves a series of reactions between the coagulation factors divided into three steps: 1) initiation, 2) amplification and 3) propagation occurring on two principal cell surfaces - the TF-bearing cells and the platelets (Walsh 2004). After the exposure of TFbearing cells into the bloodstream, TF/FVIIa complex is formed and FX is turned into FXa. However, the process is rapidly stopped by an endogenous inhibitor - tissue factor pathway inhibitor (TFPI) - which forms an inactive quaternary TF/FVIIa/FXa/TFPI complex. In this way, only small amounts of FXa are produced and only traces of thrombin are generated, incapable to cleave enough fibrinogen into fibrin. Nevertheless, the generated thrombin is sufficient to activate FV and FVIII, which then serve as cofactors and strongly enhance the production of FXa by FIXa/FVIIIa complex and subsequently the production of thrombin by $\mathrm{FXa} / \mathrm{FVa}$ complex. Furthermore, thrombin activates factor XI (FXI) into FXIa, which provides another route of activation of FIX apart from that of TF/FVIIa complex. This is in accordance with findings that people, deficient in contact factors (FXII, prekallikrein, high molecular weight kininogen) which were claimed to be responsible for FXI activation, do not suffer from bleeding, while patients deficient in FXI do, proving that there must be another route of FXI activation. TF seems to serve as a kind of starter to produce minute amounts of thrombin before its pathway is switched off and the process then continues thanks to back-activation loops leading from thrombin to FIX, FVIII and FV (Walsh 2004, Frederick et al. 2005).

\section{Molecular structure of TF}

TF is encoded by a $12.4 \mathrm{~kb}$ gene organized into six exons separated by five introns located on chromosome 1 , at locus $1 \mathrm{p} 22-23$. The promoter region exhibits two binding sites for the transcription factor activator protein-1, one $\kappa \mathrm{B}$-binding site, three Egr-a binding sites and five Ap1 sites (Mackman et al. 1989). A binding site for nuclear factor of activated $\mathrm{T}$ cells was identified as well, overlapping the $\kappa \mathrm{B}$ site (Armesilla et al. 1999).

TF is constitutively expressed in several cell types such as adventitial fibroblasts, smooth muscle cells and epithelial cells but extensive cell culture studies showed that TF promoter is capable of inducing TF expression after stimulation (by LPS, IL-1 $\beta$, TNF- $\alpha$ ) on other cell types as well (e.g. monocytes) (Eilertsen and Bjarne 2004).

$\mathrm{TF}$ is composed of an extracellular domain consisting of two fibronectin type III repeats (N-terminal domain TF1 and C-terminal domain TF2), a transmembrane domain and a short cytoplasmic tail. The crystal structure of soluble tissue factor (sTF) showed the interdomain angle to be about $120^{\circ}$ (Harlos et al. 1994, Muller et al. 1994) and a structural relationship between $\mathrm{TF}$ and the cytokine receptors (Bazan 1990). A close structural similarity of TF with cytokine receptors explains a receptor function of $\mathrm{TF}$ with intracellular signaling capacity. Several studies addressing this aspect of TF function prove the view that TF plays a role in biological actions unrelated to coagulation, such as tumor metastasis and angiogenesis (Rickles et al. 2003, Versteeg et al. 2003, Bromberg et al. 1995, Zhang et al. 1994).

\section{Expression of $T F$}

$\mathrm{TF}$ is expressed on cells in the vessel wall (Wilcox et al. 1989) and is normally not found on cells that are in direct contact with the bloodstream (Kirchhofer and Banner 1997). Various endogenous (e.g. TNF- $\alpha$ ) and exogenous agonists (e.g. lipopolysacharides) can induce TF expression on endothelial cells and monocytes (Camerer et al. 1996). This TF upregulation may play a role in thrombotic disorders. Furthermore, induction of TF expression on smooth muscle cells was observed in experimental restenosis, implicating tissue factor activity in thrombotic complications after angioplasty (Marmur et al. 1993, Speidel et al. 1995), and also in neointima proliferation (Jang et al. 1995). TF expression in atherosclerotic plaques was first described by Wilcox et al. (1989). Subsequent studies identified extensive $\mathrm{TF}$ expression in human atherectomy 
specimens (Annex et al. 1995, Marmur et al. 1996), suggesting a function of the TF pathway in the development of coronary artery diseases.

\section{Blood-borne TF}

Several studies show that an additional source of TF, known as blood-borne TF or plasma TF, may also contribute to thrombosis. According to them, TF antigen is present in plasma of healthy subjects at mean levels ranging from 149 to $172 \mathrm{pg} / \mathrm{ml}$ (Koyama et al. 1994, Albrecht et al. 1996). Some studies have shown that levels of blood-borne TF are increased in various disease states, such as atherosclerosis, sepsis, diabetes, and sickle cell disease (Semenza et al. 1990, Misumi et al. 1998, Soejima et al. 1999, Mallat et al. 1999, Nieuwland et al. 2000, Diamant et al. 2002). It was also shown that there is a correlation between levels of blood-borne TF and acute myocardial infarction (Nieuwland et al. 1997, Misumi et al. 1998, Seljeflot et al. 2003). Furthermore, inhibition of TF in a rabbit model of venous thrombosis reduced thrombus propagation (Himber et al. 1997).

The role of blood-borne TF was strongly supported by a study measuring the rate at which FX in a well-mixed clot supernatant permeates the clot and is converted to $\mathrm{FXa}$ on various in vitro prepared plateletfibrin clots on TF/VIIa-coated surfaces. Paradoxically, the growing thrombus acted as a barrier, restricting the convective and diffusive exchange of substrates and coagulation products between the blood and reactive vessel wall, thus limiting the role of TF from the vessel wall played in thrombus growth. The apparent diffusion coefficients of FX(a) in fibrin and platelet-fibrin clots at $37{ }^{\circ} \mathrm{C}$ was $2.3 \times 10^{-7}$ and $5.3 \times 10^{-10} \mathrm{~cm}^{2} / \mathrm{s}$, respectively, indicating that the mean time required for $\mathrm{FX}(\mathrm{a})$, and likely FIX(a), to diffuse $1 \mathrm{~mm}$ in a fibrin clot is 4 hours, and 3.6 months in the presence of platelets. As complete human thrombotic occlusion has been observed within 10 min, an alternative source of procoagulant activity that can be localized to the outer surface of growing thrombi (such as platelet factor XI or blood-borne TF) appears to be essential for rapid thrombus growth (Hathcock and Nemerson 2004).

One controversial issue is the form of bloodborne TF. Many studies have shown that TF circulates in the blood in the form of cell-derived microparticles (Nieuwland et al. 1997, Combes et al. 1999, Berckmans et al. 2001, Sturk-Maquelin et al. 2003). Other groups suggest that TF is present in platelets (Siddiqui et al. 2002, Camera et al. 2003, Muller et al. 2003). Finally, it was recently proposed that an alternatively spliced form of soluble TF is the major form of blood-borne TF
(Bogdanov et al. 2003). Monocytes were shown to be capable of shedding microparticles exposing TF and phosphatidylserine together with adhesion molecules CD14, CD11a and CD18 after LPS stimulation (Eilertsen and Osterud 2005). It was found that this TF on microparticles became incorporated into spontaneous human thrombi, suggesting that TF may be transferred to platelets by interaction of CD15 with P-selectin exposed on activated platelets (Giesen et al. 1999). TF itself plays a role of adhesion molecule necessary for this transfer. These findings were supported by the fact that anti-CD15 antibodies abolish $80 \%$ of the LPS-induced TF activity in monocytes of cell suspensions recombined with platelet-rich plasma (Halvorsen et al. 1993). Furthermore, mice lacking P-selectin or PSGL-1 developed plateletrich thrombi with minimal TF and fibrin (Falati et al. 2003). Leukocyte-platelet interactions associated with the release of TF and subsequently thrombin are suspected to play an important role in various hyperthrombotic states in patients with high LDL cholesterol concentrations, cigarette smoking and diabetes mellitus, thus emphasizing the importance of not only the vulnerable or highrisk atherothrombotic lesions but also the relevance of hyperreactive or vulnerable blood. This explains a possible mechanism of thrombus formation in those cases of acute coronary syndromes that are based only on a superficial erosion of the fibrotic plaque and not on a disruption of a lipid-rich plaque exposing the lipid core with high levels of TF.

Small amounts of microparticles with TF probably originate from apoptotic cells. The role of apoptosis in atherothrombosis is important both at the site of the plaque and in the circulation (Viles-Gonzalez et al. 2005). Apoptosis within atheromas involves all cell types and it has been demonstrated that it coexists with high levels of TF within the plaque. TF activity is dependent on the presence of phosphatidylserine, exposure of which is associated with apoptosis. The prothrombotic potential of apoptotic cells was also shown to be present in the circulation because one group found high levels of endothelial membrane microparticles in the circulating blood of patients with acute coronary syndrome (ACS), inferring that they might participate in the generation and perpetuation of intracoronary thrombi (Mallat et al. 2000).

Another significant issue with blood-borne TF is how to measure its functional levels. It is clear that the levels of blood-borne TF are very low compared with TF levels in the vessel wall, particularly in healthy subjects (Mackman 2004). In addition, microparticles in the blood have TF-dependent and TF-independent procoagulant activity (Berckmans et al. 2001, Aras et al. 2004). A 
recent study described a novel assay that overcomes this problem by measuring TF activity of selectively captured, TF-positive microparticles. This study also showed that elevation of procoagulant microparticles, a subset of which contained TF, restored hemostasis in hemophilic mice (Hrachovinová et al. 2003). Moreover, FVIIa has been proven to be a very effective hemostatic agent in hemophilic patients and in trauma patients (Hedner 2000). The mechanism of action of FVIIa has been proposed to be independent of TF (Hoffman et al. 1994). However, the presence of blood-borne TF suggests that this conclusion should be re-evaluated. It seems to be possible that the hemostatic protection provided by FVIIa may be, in part, caused by its binding to blood-borne TF (Mackman 2004).

\section{Tissue-specific TF distribution}

$\mathrm{TF}$ exhibits a non-uniform tissue distribution with high levels in the brain, lung, and placenta, intermediate levels in the heart, kidney, intestine, uterus and testes, and low levels in the spleen, thymus, skeletal muscle and liver (Bach 1988, Drake et al. 1989, Hartzell et al. 1989, Faulk et al. 1990, Mackman et al. 1993). Immunohistochemical and in situ hybridization studies demonstrated that high levels of TF were expressed by astrocytes in the brain, alveolar cells in the lung, trophoblasts in the placenta, epithelial cells surrounding organs and at body surfaces, adventitial fibroblasts surrounding blood vessels, and cardiac myocytes in the heart (Drake et al. 1989, Fleck et al. 1990, Eddleston et al. 1993, Mackman et al. 1993, Flossel et al. 1994, Luther et al. 1996). This cell type-specific distribution suggested that TF provides a "hemostatic envelope" to limit bleeding after vessel injury (Drake et al. 1989). The higher levels of TF in the brain, lung, placenta, heart, and uterus would provide additional hemostatic protection to these vital organs. In contrast, tissues that express low levels of TF, such as skeletal muscles and joints, rely on the FVIIIa/FIXa complex of the intrinsic pathway to prevent bleeding. Indeed, this model explains why hemophilia patients deficient in either FVIII or FIX frequently bleed into joints and soft tissues (BoltonMaggs and Pasi 2003).

TF is constitutively expressed in cardiac myocytes but not in skeletal myocytes (Drake et al. 1989). The likely function of TF in the heart is to provide additional hemostatic protection. Low-TF mice had very low levels of TF in their hearts compared with the level sof TF in the hearts of wild-type mice, suggesting reduced TF expression in cardiac myocytes. Importantly, low-TF mice and low-FVII mice exhibited hemosiderin deposition and fibrosis in their hearts. It is believed that the hemosiderin is derived from erythrocytes hemorrhaging into the myocardium and phagocyte digestion of the hematin. Indeed, occasional hemorrhages in the hearts of low-TF mice were observed (Pawlinski et al. 2002). Taken together, these results suggest that low-TF and low-FVII mice have impaired heart hemostasis. It has been found that overexpression of murine TF in the cardiac myocytes abolishes fibrosis in the hearts of low-TF mice. These results indicate that TF expression in cardiac myocytes plays a key role in the heart, most likely by providing additional hemostatic protection to this vital organ that may be prone to mechanical injury of the vessels. In contrast, FIXdeficient mice have normal hearts (Mumford and McVey 2004). These results suggest that the TF/FVIIa complex, but not the FVIIIa/FIXa complex, plays a critical role in heart hemostasis.

FIX and other factors of the amplification stage of blood coagulation normally provide an important backactivation loop, thus enhancing thrombin generation. However, some computer-generated models showed that high concentrations of TF (for example in the conditions of sepsis or endotoxemia) provide enough FXa and enough thrombin to generate a fibrin clot without this back-activation loop (Pawlinski and Mackman 2004).

\section{Role of TF in thrombosis}

Aberrant TF expression triggers intravascular thrombosis associated with various diseases, such as atherosclerosis, cancer and sepsis (Rao 1992, Creasey et al. 1993, Tremoli et al. 1999, Rickles et al. 2003). Importantly, inhibition of TF/FVIIa complex activity reduced coagulation and decreased mortality in animal models of sepsis (Taylor et al. 1991, 1998). In atherosclerosis, TF is expressed (apart from other cells) by macrophage-derived foam cells within atherosclerotic plaques (Wilcox et al. 1989). These results strongly suggest that high levels of TF exposed upon plaque rupture trigger thrombosis and myocardial infarction. Thus, the classical view of TF is that it is expressed locally within an atherosclerotic lesion. Inhibition of TF would be expected to reduce thrombosis associated with a variety of diseases.

The role of TF and FVII in coronary no-reflow was also studied. The data obtained suggest that active $\mathrm{TF}$ is released from dissected coronary atherosclerotic plaque and is one of the factors causing the no-reflow phenomenon (Bonderman et al. 2002).

Functional inhibition of TF with an anti-rabbit $\mathrm{TF}$ monoclonal antibody in a rabbit coronary ligation 
model has been shown to improve coronary blood flow after myocardial ischemia/reperfusion (I/R) injury. At-risk areas of myocardium showed increased $\mathrm{TF}$ expression in the sarcolemma of cardiomyocytes, which was associated with a low level of extravascular fibrin deposition. Infarct size was reduced by $61 \%$ and $44 \%$, respectively (Erlich et al. 2000).

Local inhibition of TF by both recombinant tissue factor pathway inhibitor and a polyclonal antibody against human $\mathrm{TF}$ reduces the thrombogenicity of disrupted human atherosclerotic plaques in an in vitro model of human atherosclerotic and normal arterial segments exposed to heparinized blood at flow conditions modeling medium-grade coronary stenosis (Badimon et al. 1999). The antithrombotic effects of the specific inhibition of plaque TF was assessed by reduction in the deposition of radiolabeled platelets and fibrinogen and immunohistochemical analysis of perfused arteries.

\section{TF role in embryonic development}

As there are no known TF-deficient humans, some groups studied the effect of knocked-out murine TF gene and they all reported high rate of lethality of embryos (approximately 90 \%) (Bugge et al. 1996, Carmeliet et al. 1996). Defect of hemostasis was considered to be the cause of death, but flawed development of the yolk sac vasculature was also noted (Toomey et al. 1996). Controversial were findings that FVII deficient embryos survive the embryonic development (Rosen et al. 1997). Using a transgenic approach the role of several coagulation factors and PARs (protease-activated receptors) in the embryonic development was studied with the conclusion that the high rate of lethality of TF-deficient embryos may be caused by a loss of both hemostatic and non-hemostatic pathways and an absence of maternal rescue of this transmembrane receptor (Carmeliet et al. 1996).

\section{Inhibition of early steps of the coagulation cascade}

The study of TF role in blood coagulation leads to new ideas in anticoagulation therapy. New drugs are expected to be found, with less side effects and stronger anticoagulation potential when acting at the beginning of the coagulation cascade.

The possible influence of TF transcription was reported by a group demonstrating that activation of liver $\mathrm{X}$ receptors (LXRs) LXR $\alpha$ and LXR $\beta$ suppresses TF expression. Treatment of mouse peritoneal macrophages with synthetic LXR agonist T0901317 or GW3965 reduced TF expression induced by pro-inflammatory stimuli. LXR agonists also suppressed TF expression and its activity in human monocytes. Human and mouse TF promoters contain binding sites for the transcription factors AP-1, NFאB, Egr-1 and Sp1, but no LXR-binding sites could be found. Cotransfection assays with LXR and TF promoter constructs revealed that LXR agonists suppressed LPS-induced TF promoter activity. Analysis of TF promoter also showed that inhibition of TF promoter activity by LXR was at least in part mediated by inhibition of the NFאB signaling pathway. In addition, LXR agonists reduced in vivo TF expression within aortic lesions in an atherosclerosis mouse model as well as in the kidney and lung of mice stimulated with LPS. These findings indicate that activation of LXR results in the reduction of TF expression, which may influence atherothrombosis in patients with vascular disease (Terasaka et al. 2005).

A lot of effort has been made to inhibit the TF gene expression at the translational level using various approaches involving ribozymes, antisense technologies and RNA interference (Zhang et al. 1996, Armesilla et al. 1999, Cavusoglu et al. 2002). However these techniques seem to have limited efficiency and still need to develop an effective and safe delivery mechanism (Armesilla et al. 1999).

Direct blocking of the TF, FVIIa or TF/FVIIa complex activity can be achieved by various inhibitors. One way of blocking the TF-mediated start of coagulation is using a specific antibody. In a recently published study Morrow et al. (2005) used Sunol-cH36, a chimeric monoclonal antibody to $\mathrm{TF}$, which blocks binding of factor $\mathrm{X}$ to the TF/VIIa complex, for a trial in humans. The safety and pharmacokinetics of Sunol-cH36 were assessed in an open-label, dose-escalating trial among subjects with stable coronary artery disease. No major bleeding ( $\geq 2 \mathrm{~g} / \mathrm{dl}$ hemoglobin decline) was reported. Spontaneous minor bleeding was observed with a dose-related pattern. The majority of spontaneous bleeding episodes were clinically consistent with plateletmediated bleeding (e.g. gum, tongue) without thrombocytopenia. Sunol-cH36 exhibited dose-dependent anticoagulant effects and the mucosal bleeding observed with this potent inhibitor of thrombin generation may reflect antiplatelet effects resulting from networking between the coagulation cascade and platelet pathways that could prove clinically relevant with this novel class of anticoagulants (Morrow et al. 2005).

A recombinant version of the truncated, extracellular form of TF (hTFAA) has also been reported to function as an antagonist of membrane-bound TF (Kelley et al. 1997). Promising investigation was presented of a selective small-molecule TF inhibitor 
PHA-927F, which is capable efficiently inhibit or prevent acute thrombosis without any increase in the risk of bleeding thanks to its great selectivity against TF when compared to other coagulation factors as a result of extensive crystal structure studies of similar molecules (Suleymanov et al. 2003, Frederick et al. 2005).

Stone et al. (2005) showed the effect of active site-inhibited FVIIa (FVIIai) binding to TF. FVIIai blocks binding of the corresponding enzyme (FVIIa) or zymogen (FVII) forms of FVII and inhibits coagulation. Although several studies have suggested that FVIIai may have superior anticoagulation effects in vivo, a challenge for use of FVIIai is the cost of its production. The study reported the properties of dimeric forms of FVIIai that are cross-linked through their active sites. Dimeric wild-type FVIIai was at least 75-fold more effective than monomeric FVIIai in blocking FVIIa association with TF. The dimer of a mutant FVIIai with higher membrane affinity was 1600 -fold more effective. Anticoagulation by any form of FVIIai differed substantially from agents such as heparin and showed a delayed mode of action. Coagulation proceeded normally for the first minutes, and the inhibition increased when equilibrium binding was established. It is suggested that association of FVIIa(i) with $\mathrm{TF}$ in a collision-dependent reaction gives equal access of inhibitor and enzyme to TF. Assembly was not influenced by the higher affinity and slower dissociation of the dimer. As a result, anticoagulation was delayed until the reaction reached equilibrium. Different dissociation experiments suggested that dissociation of FVIIai from TF occurred by a two-step mechanism. The first step was a separation of TF/FVIIa(i) while both proteins remained bound to the membrane. The second step was a dissociation of the FVIIa(i) from the membrane. These results suggest novel actions of FVIIa(i) that distinguish it from most of the anticoagulants that block later steps of the coagulation cascade (Stone et al. 2005).

Some studies of a novel class of peptide exosite inhibitors of FVIIa (like E-76, A-183 or extended A-183X) have been performed. Among these, A-183X is capable of an almost complete in vitro inhibition of TF/FVIIa activity. The NAPc2 (Nematod Anticoagulant Protein c2) isolated from the canine hookworm
Ancylostoma caninum, binds to $\mathrm{FXa}$ and then to TF/FVIIa complex and forms an inactive quaternary complex (Walsh 2004, Frederick et al. 2005).

Roque et al. (2000) investigated the effect of TF inhibition by recombinant tissue factor pathway inhibitor (rTFPI) on thrombus formation and intimal hyperplasia in a porcine model of coronary balloon angioplasty. Tissue factor pathway inhibitor (TFPI) is the principal physiological inhibitor of the TF-factor VII/VIIa complex and is found mainly in endothelial cells. TFPI therapy has been proven as beneficial in deep vein thrombosis (Holst et al. 1994), in preventing arterial reocclusion after fibrinolysis (Abendschein et al. 1995) and in reducing intimal hyperplasia in experimental models of arterial injury (Jang et al. 1995, Oltrona et al. 1997). Using an ex vivo perfusion system it has previously been shown that specific inhibition of TF with TFPI reduces thrombogenicity of disrupted human aortic atherosclerotic plaques (Badimon et al. 1999).

The potential use of TFPI after angioplasty was also studied in a rabbit model. When the TFPI gene in a liposome or in an adenoviral vector was locally administered after iliac and carotid artery angioplasty, restenosis was markedly reduced (Zoldhelyi et al. 2001, Yin et al. 2002).

\section{Conclusions}

In this review we have summarized essentials of the physiology and the pathophysiology of TF in terms available literary sources. There are still many questions to be answered: the source and the level of TF in healthy subjects, the method how to measure the "thrombogenic" potential of $\mathrm{TF}$ because its role in many biological processes, "normal" levels and the possible impact of risk factors and possibility of risk stratification of "healthy" subjects according to the levels of TF as markers of the blood with a procoagulant potential. Answering these questions and the impact of TF blocking as a therapeutical approach in acute coronary syndromes is a challenging field of investigation in blood coagulation.

\section{Acknowledgements}

Grant of the Ministry of Health of the Czech Republic No. 00064203.

\section{References}

ABENDSCHEIN DR, MENG YY, TORR-BROWN S, SOBEL BE: Maintenance of coronary patency after fibrinolysis with tissue factor pathway inhibitor. Circulation 92: 944-949, 1995. 
ALBRECHT S, KOTZSCH M, SIEGERT G, LUTHER T, GROSSMAN H, GROSSER M, MULLER M: Detection of circulating tissue factor and factor VII in a normal population. Thromb Haemost 75: 772-777, 1996.

ANNEX BH, DENNING SM, CHANNON KM, SKETCH MH JR, STACK RS, MORRISEY JH, PATERS KG: Differential expression of tissue factor protein in directional atherectomy specimens from patients with stable and unstable coronary syndromes. Circulation 91: 619-622, 1995.

ARAS O, SHET A, BACH RR, HYSJULIEN JL, SLUNGAARD A, HEBBEL RP, ESCOLAR G, JILMA B, KEY NS: Induction of microparticle- and cell-associated intravascular tissue factor in human endotoxemia. Blood 103: 4545-4553, 2004.

ARMESILLA AL, LORENZO E, GOMEZ DEL ARCO P: Vascular endothelial growth factor activates nuclear factor of activated T cells in human endothelial cells: a role for tissue factor gene expression. Mol Cell Biol 59: 421437, 1999.

BADIMON JJ, LETTINO M, TOSCHI V, FUSTER V, BERROZPE M, CHESEBRO JH, BADIMON L: Local inhibition of tissue factor reduces the thrombogenicity of disrupted human atherosclerotic plaques. Effects of tissue factor pathway inhibitor on plaque thrombogenicity under flow conditions. Circulation 99: 1780-1787, 1999.

BACH RR: Initiation of coagulation by tissue factor. Crit Rev Biochem 23: 339-368, 1988.

BANNER DW, D'ARCY A, CHENE C, WINKLER FK, GUHA A, KONIGSBERG WH, NEMERSON Y, KIRCHHOFER D: The crystal structure of the complex of blood coagulation factor VIIa with soluble tissue factor. Nature 380: 41-46, 1996.

BAZAN JF: Structural design and molecular evolution of a cytokine receptor superfamily. Proc Natl Acad Sci USA 87: 6934-6938, 1990.

BERCKMANS RJ, NIEUWLAND R, BOING AN, ROMIJN FP, HACK CE, STURK A: Cell-derived microparticles circulate in healthy humans and support low grade thrombin generation. Thromb Haemost 85: 639-646, 2001.

BOGDANOV VY, BALASUBRAMANIAN V, HATHCOCK J, VELE O, LIEB M, NEMERSON Y: Alternatively spliced human tissue factor: a circulating, soluble, thrombogenic protein. Nat Med 9: 458-462, 2003.

BOLTON-MAGGS PH, PASI KJ: Haemophilias A and B. Lancet 361: 1801-1809, 2003.

BONDERMAN D, TEML A, JAKOWITSCH J, ADLBRECHT CH, GYÖNGÖSI M, SPERKER W, LASS H, MOSGOELLER W, GLOGAR DH, PROBST P, MAURER G, NEMERSON Y, LANG IM: Coronary noreflow is caused by shedding of active tissue factor from dissected atherosclerotic plaque. Blood 99: 2794$2800,2002$.

BROMBERG ME, KONIGSBERG WH, MADISON JF, PAVASHE A, GAREN A: Tissue factor promotes melanoma metastasis by a pathway independent of blood coagulation. Proc Natl Acad SciUSA 92: 8205-8209, 1995.

BUGGE TH, XIAO Q, KOMBRINCK KW, FLICK MJ, HOLMBÄCK K, DANTON MS, COLBERT MC, WITTE DP, FUJIKAVA K, DAVIE EW, DEGEN JL: Fatal embryonic bleeding events in mice lacking tissue factor, the cell-associated initiator of blood coagulation. Proc Natl Acad SciUSA 93: 6258-6263, 1996.

CAMERA M, FRIGERIO M, TOSCHI V, BRAMBILLA M, ROSSI F, COTTELL DC, MADERNA P, PAROLARI A, BONZI R, DE VINCENTI O, TREMOLI E: Platelet activation induces cell-surface immunoreactive tissue factor expression, which is modulated differently by antiplatelet drugs. Arterioscler Thromb Vasc Biol 23: 1690-1696, 2003.

CAMERER E, KOLSTO AB, PRYDZ H: Cell biology of tissue factor, the principal initiator of blood coagulation. Thromb Res 81: 1-41, 1996.

CARMELIET P, MACKMAN N, MOONS L, LUTHER T, GRESSENS P, VAN VLAENDEREN I, DEMUNCK H, KASPER M, BREIER G, EVRARD P, MULLER M, RISAU W, EDGINGTON T, COLLEN D: Role of tissue factor in embryonic blood vessel development. Nature 383: 73-75, 1996.

CAVUSOGLU E, CHEN I, RAPPAPORT J, MARMUR JD: Inhibition of tissue factor gene induction and activity using a hairpin ribozyme. Circulation 105: 2282-2287, 2002.

COMBES V, SIMON AC, GRAU GE, ARNOUX D, CAMOIN L, SABATIER F, MUTIN M, SANMARCO M, SAMPOL J, DIGNAT-GEORGE F: In vitro generation of endothelial microparticles and possible prothrombotic activity in patients with lupus anticoagulant. J Clin Invest 104: 93-102, 1999. 
CREASEY AA, CHANG AC, FEIGEN L, WUN TC, TAYLOR FB JR, HINSHAV LB: Tissue factor pathway inhibitor reduces mortality from Escherichia coli septic shock. J Clin Invest 91: 2850-2856, 1993.

DIAMANT M, NIEUWLAND R, PABLO RF, STURK A, SMIT JW, RADDER JK: Elevated numbers of tissue-factor exposing microparticles correlate with components of the metabolic syndrome in uncomplicated type 2 diabetes mellitus. Circulation 106: 2442-2447, 2002.

DRAKE TA, MORRISSEY JH, EDGINGTON TS: Selective cellular expression of tissue factor in human tissues. Am J Pathol 134: 1087-1097, 1989.

EDDLESTON M, DE LA TORRE JC, OLDSTONE MB, LOSKUTOFF DJ, EDGINGTON TS, MACKMAN N: Astrocytes are the primary source of tissue factor in the murine central nervous system - a role for astrocytes in cerebral hemostasis. J Clin Invest 92: 349-358, 1993.

EILERTSEN KE, BJARNE O: Tissue factor: (patho)physiology and cellular biology. Blood Coagul Fibrinolysis 15: 521-538, 2004.

EILERTSEN KE, OSTERUD B: The role of blood cells and their microparticles in blood coagulation. Biochem Soc Trans 33: 418-422, 2005.

ERLICH JH, BOYLE EM, LABRIOLA J, KOVACICH JC, SANTUCCI RA, FEARNS C, MORGAN EN, YUN W, LUTHER T, KOJIKAVA O, MARTIN TR, POHLMAN TH, VERRIER ED, MACKMAN N: Inhibition of the tissue factor-thrombin pathway limits infarct size after myocardial ischemia-reperfusion injury by reducing inflammation. Am J Pathol 157: 1849-1862, 2000.

FALATI S, LIU Q, GROSS P, MERRILL-SKOLOFF G, CHOU J, VANDENDRIES E, CELI A, CROCE K, FURIE $\mathrm{BC}$, FURIE B: Accumulation of tissue factor into developing thrombi in vivo is dependent upon microparticle P-selectin glycoprotein ligand 1 and platelet P-selectin. J Exp Med 197: 1585-1598, 2003.

FAULK WP, LABARRERE CA, CARSON SD: Tissue factor: identification and characterization of cell types in human placentae. Blood 76: 86-96, 1990.

FLECK RA, RAO LV, RAPAPORT SI, VARKI N: Localization of human tissue factor antigen by immunostaining with monospecific, polyclonal anti-human tissue factor antibody. Thromb Res 57: 765-781, 1990.

FLOSSEL C, LUTHER T, MULLER M, ALBRECHT S, KASPER M: Immunohistochemical detection of tissue factor (TF) on paraffin sections of routinely fixed human tissue. Histochemistry 101: 449-453, 1994.

FREDERICK R, POCHET L, CHARLIER C, MASEREEL B: Modulators of the coagulation cascade: focus and recent advances in inhibitors of tissue factor, factor VIIa and their complex. Curr Med Chem 12: 397-417, 2005.

GIESEN PL, RAUCH U, BOHRMANN B, KLING D, ROQUE M, FALLON JT, BADIMON JJ, HIMBER J, RIEDERER MA, NEMERSON Y: Blood borne tissue factor: another view of thrombosis. Proc Natl Acad Sci USA 96: 2311-2315, 1999.

HALVORSEN H, OLSEN JO, OSTERUD B: Granulocytes enhance LPS-induced tissue factor activity in monocytes via an interaction with platelets. J Leukoc Biol 54: 275-282, 1993.

HARLOS K, MARTIN DM, O'BRIEN DP, JONES EY, STUART DI, POLIKARPOV I, MILLER A, TUDDENHAM EG, BOYS CW: Crystal structure of the extracellular region of human tissue factor. Nature 370: 662-666, 1994.

HARTZELL S, RYDER K, LANAHAN A, LAU LF, NATHAN D: A growth factor responsive gene of murine BALB/c 3T3 cells encodes a protein homologous to human tissue factor. Mol Cell Biol 9: 2567-2573, 1989.

HATHCOCK JJ, NEMERSON Y: Platelet deposition inhibits tissue factor activity: in vitro clots are impermeable to factor Xa. Blood 104: 123-127, 2004.

HEDNER U: NovoSeven as a universal haemostatic agent. Blood Coagul Fibrinolysis 11: 107-111, 2000.

HIMBER J, KIRCHHOFER D, RIEDERER M, TSCHOPP TB, STEINER B, ROUX SP: Dissociation of antithrombotic effect and bleeding time prolongation in rabbits by inhibiting tissue factor function. Thromb Haemost 78: 1142-1149, 1997.

HOFFMAN M, MONROE DM, ROBERTS HR: Human monocytes support factor X activation by factor VIIa, independent of tissue factor: implications for the therapeutic mechanism of high-dose factor VIIa in hemophilia. Blood 83: 38-42, 1994. 
HOLST J, LINDBLAD B, BERGQVIST D, NORDFANG O, OSTERGAARD PB, PETERSEN JG, NIELSEN G, HEDNER U: Antithrombotic effect of recombinant truncated tissue factor pathway inhibitor (TFPI1-161) in experimental venous thrombosis -a comparison with low molecular weight heparin. Thromb Haemost 71: $214-$ 219, 1994.

HRACHOVINOVA I, CAMBIEN B, HAFEZI-MOGHADAM A, KAPPELMAYER J, CAMPHAUSEN RT, WIDOM A, XIA L, KAZAZIAN HH JR, SCHAUB RG, MCEVER RP, WAGNER DD: Interaction of P-selectin and PSGL-1 generates microparticles that correct hemostasis in a mouse model of hemophilia A. Nat Med 9: 10201025, 2003.

JANG Y, GUZMAN LA, LINCOFF AM, GOTTSAUNER-WOLF M, FORUDI F, HART CH, COURTMAN DW, EZBAN M, ELLIS SG, TOPOL EJ: Influence of blockade at specific levels of the coagulation cascade on restenosis in a rabbit atherosclerotic femoral artery injury model. Circulation 92: 3041-3050, 1995.

KELLEY RF, REFINO CJ, O’CONNELL MP, MODI N, SEHL P, LOVE D, PATER CH, BUNTING S: A soluble tissue factor mutant is a selective anticoagulant and antithrombotic agent. Blood 89: 3219-3227, 1997.

KIRCHHOFER D, BANNER DW: Molecular and structural advances in tissue factor-dependent coagulation. Trends Cardiovasc Med 7: 316-324, 1997.

KOYAMA T, NISHIDA K, OHDAMA S, SAVADA M, MURAKAMI N, HIROSAVA S, KURIYAMA R, MATSUZAVA K, HASEGAVA R, AOKI N: Determination of plasma tissue factor antigen and its clinical significance. Br J Haematol 87: 343-347, 1994.

LUTHER T, FLOSSEL C, MACKMAN N, BIERHAUS A, KASPER M, ALBRECHT S, SAGE EH, IRUELAARISPE L, GROSSMANN H, STROHLEIN A, ZHANG Y, NAVROTH PP, CARMELIET P, LOSKUTOFF DJ, MULLER M: Tissue factor expression during human and mouse development. Am J Pathol 149: 101-113, 1996.

MACKMAN N: Role of tissue factor in hemostasis, thrombosis, and vascular development. Arterioscler Thromb Vasc Biol 24: 1015-1022, 2004.

MACKMAN N, MORRISEY JH, FOWLER B, EDGINGTON TS: Complete sequence of the human tissue factor gene, a highly regulated cellular receptor that initiates the coagulation protease cascade. Biochemistry 28: 1755-1762, 1989.

MACKMAN N, SAWDEY MS, KEETON MR, LOSKUTOFF DJ: Murine tissue factor gene expression in vivo: Tissue and cell specificity and regulation by lipopolysaccharide. Am J Pathol 143: 76-84, 1993.

MALLAT Z, HUGEL B, OHAN J, LESÉCHE G, FREYSSINET JM, TEDGUI A: Shed membrane microparticles with procoagulant potential in human atherosclerotic plaques: a role for apoptosis in plaque thrombogenicity. Circulation 99: 348-353, 1999.

MALLAT Z, BENAMER H, HUGEL B, BENESSIANO J, STEG G, FREYSSINET JM, TEDGUI A: Elevated levels of shed membrane microparticles with procoagulant potential in the peripheral circulating blood of patients with acute coronary syndromes. Circulation 101: 841-843, 2000.

MARMUR JD, ROSSIKHINA M, GUHA A, FYFE B, FRIEDRICH V, MENDLOVITZ M, NEMERSON Y, TAUBMAN MB: Tissue factor is rapidly induced in arterial smooth muscle after balloon injury. J Clin Invest 91: 2253-2259, 1993.

MARMUR JD, THIRUVIKRAMAN SV, FYFE BS, GUHA A, SHARMA SK, AMBROSE JA, FALKON JT, NEMERSON Y, TAUBMAN MB: Identification of active tissue factor in human coronary atheroma. Circulation 94: 1226-1232, 1996.

MISUMI K, OGAWA H, YASUE H, SOEJIMA H, NISHIYAMA K, TAKAZOE K, KUGIYAMA K, TSUJI I, KUMEDA K, NAKAMURA S: Comparison of plasma tissue factor levels in unstable and stable angina pectoris. Am J Cardiol 81: 22-26, 1998.

MORROW DA, MURPHY SA, MCCABE CH, MACKMAN N, WONG HC, ANTRMAN EM: Potent inhibition of thrombin with a monoclonal antibody against tissue factor (Sunol-cH36): results of the PROXIMATE-TIMI 27 trial. Eur Heart J 26: 682-688, 2005.

MULLER YA, ULTSCH MH, KELLEY RF, VOS AM: Structure of the extracellular domain of human tissue factor: location of the factor VIIa binding site. Biochemistry 33: 10864-10870, 1994. 
MULLER I, KLOCKE A, ALEX M, KOTZSCH M, LUTHER T, MORGENSTERN E, ZIESENISS S, ZAHLER S, PREISSNER K, ENGELMAN B: Intravascular tissue factor initiates coagulation via circulating microvesicles and platelets. FASEB J 17: 476-478, 2003.

MUMFORD AD, MCVEY JH: Tissue factor in the myocardium: Evidence of roles in haemostasis and inflammation. Dis Markers 20: 353-358, 2004.

NEMERSON Y: Tissue factor and hemostasis. Blood 71: 1-8, 1988.

NIEUWLAND R, BERCKMANS RJ, ROTTEVEEL-EIJKMAN RC, MAQUELIN KN, ROOZENDAAL KJ, JANSEN PG, TEN HAVE K, EIJSMAN L, HACK CE, STURK A: Cell-derived microparticles generated in patients during cardiopulmonary bypass are highly procoagulant. Circulation 96: 3534-3541, 1997.

NIEUWLAND R, BERCKMANS RJ, MCGREGOR S, BÖING AN, ROMIJN M, WESTENDORP RG, HACK CE, STURK A: Cellular origin and procoagulant properties of microparticles in meningococcal sepsis. Blood 95 : 930-935, 2000.

OLTRONA L, SPEIDEL CM, RECCHIA D, WICKLINE SA, EISENBERG PR, ABENCHEIN DR: Inhibition of tissue factor-mediated coagulation markedly attenuates stenosis after balloon-induced arterial injury in minipigs. Circulation 96: 646-652, 1997.

PAWLINSKI R, MACKMAN N: Tissue factor, coagulation proteases, and protease-activated receptors in endotoxemia and sepsis. Crit Care Med 32: 293-297, 2004.

PAWLINSKI R, FERNANDES A, KEHRLE B, PEDERSEN B, PARRY G, ERLICH J, PYO R, GUTSTEIN D, ZHANG J, CASTELLINO F, MELIS E, CARMELIET P, BARETTON G, LUTHER T, TAUBMAN M, ROSEN E, MACKMAN N: Tissue factor deficiency causes cardiac fibrosis and left ventricular dysfunction. Proc Natl Acad Sci USA 99: 15333-15338, 2002.

RAO LV: Tissue factor as a tumor procoagulant. Cancer Metastasis Rev 11: 249-266, 1992.

RICKLES FR, PATIERNO S, FERNANDEZ PM. Tissue factor, thrombin, and cancer. Chest 124: 58-68, 2003.

ROQUE M, REIS ED, FUSTER V, PADUREAN A, FALLON JT, TAUBMAN MB, CHESEBRO JH, BADIMON JJ: Inhibition of tissue factor reduces thrombus formation and intimal hyperplasia after porcine coronary angioplasty. J Am Coll Cardiol 36: 2303-2310, 2000.

ROSEN ED, CHAN JC, IDUSOGIE E, CLOTMAN F, VLASUK G, LUTHER T, JALBERT LR, ALBRECHT S, ZHONG L, LISSENS A, SCHOONJANS L, MOONS L, COLLEN D, CASTELLINO FJ, CARMELIET P: Mice lacking factor VII develop normally but suffer fatal perinatal bleeding. Nature 390: 290-294, 1997.

RUF W: The interaction of activated factor VII with tissue factor: insight into the mechanism of cofactor-mediated activation of activated factor VII. Blood Coagul Fibrinolysis 9 (Suppl 1): S73-S78, 1998.

SELJEFLOT I, HURLEN M, HOLE T, ARNESEN H: Soluble tissue factor as predictor of future events in patients with acute myocardial infarction. Thromb Res 111: 369-372, 2003.

SEMENZA GL, DUREZA RC, TRAYSTMAN MD, GEARHART JD, ANTONARAKIS SE: Human erythropoietin gene expression in transgenic mice: multiple transcription initiation sites and cis-acting regulatory elements. Mol Cell Biol 10: 930-938, 1990.

SIDDIQUI FA, DESAI H, AMIRKHOSRAVI A, AMAYA M, FRANCIS JL: The presence and release of tissue factor from human platelets. Platelets 13: 247-253, 2002.

SOEJIMA H, OGAWA H, YASUE H, KAIKITA K, NISHIYAMA K, MISUMI K, TAKAZOE K, MIYAO Y, YOSHIMURA M, KUGIYAMA K, NAKAMURA S, TSUJI I, KUMEDA K: Heightened tissue factor associated with tissue factor pathway inhibitor and prognosis in patients with unstable angina. Circulation 99: 2908-2913, 1999.

SPEIDEL CM, EISENBERG PR, RUF W, EDGINGTON TS, ABENDSCHEIN DR: Tissue factor mediates prolonged procoagulant activity on the luminal surface of balloon-injured aortas in rabbits. Circulation 92: 3323-3330, 1995.

STONE MD, HARVEY SB, MARTINEZ MB, BACH RR, NELSESTUEN GL: Large enhancement of functional activity of active site-inhibited factor VIIa due to protein dimerization: insights into mechanism of assembly/disassembly from tissue factor. Biochemistry 44: 6321-6330, 2005.

STURK-MAQUELIN KN, NIEUWLAND R, ROMIJN FP, EIJSMAN L, HACK CE, STURK A: Pro- and noncoagulant forms of non-cell-bound tissue factor in vivo. J Thromb Haemost 1: 1920-1926, 2003. 
SULEYMANOV OD, SZALONY JA, SALYERS AK, LA CHANCE RM, PARLOV JJ, SOUTH MS, WOOD RS, NICHOLSON NS: Pharmacological interruption of acute thrombus formation with minimal hemorrhagic complications by a small molecule tissue factor/factor VIIa inhibitor: comparison to factor Xa and thrombin inhibition in a nonhuman primate thrombosis model. J Pharmacol Exp Ther 306: 1115-1121, 2003.

TAYLOR FB JR, CHANG A, RUF W, MORRISSEY JH, HUNSHAV L, CATLETT R, BLICK K, EDGINGTON TS: Lethal. E. coli septic shock is prevented by blocking tissue factor with monoclonal antibody. Circ Shock 33: 127-134, 1991.

TAYLOR FB, CHANG AC, PEER G, LI A, EZBAN M, HEDNER U: Active site inhibited factor VIIa (DEGR VIIa) attenuates the coagulant and interleukin- 6 and -8 , but not tumor necrosis factor, responses of the baboon to LD100 Escherichia coli. Blood 91: 1609-1615, 1998.

TERASAKA N, HIROSHIMA A, ARIGA A, HONZUMI S, KOIEYAMA T, INABA T, FUJIVARA T: Liver X receptor agonists inhibit tissue factor expression in macrophages. FEBS J 272: 1546-1556, 2005.

TOOMEY JR, KRATZER KE, LASKY NM, STANTON JJ, BROZE GJ JR: Targeted disruption of the murine tissue factor gene results in embryonic lethality. Blood 88: 1583-1587, 1996.

TREMOLI E, CAMERA M, TOSCHI V, COLLI S: Tissue factor in atherosclerosis. Atherosclerosis 144: 273-283, 1999.

VERSTEEG HH, PEPPELENBOSCH MP, SPEK CA: Tissue factor signal transduction in angiogenesis. Carcinogenesis 24: 1009-1013, 2003.

VILES-GONZALEZ JG, FUSTER V, BADIMON JJ: Thrombin/inflammation paradigms: A closer look at arterial and venous thrombosis. Am Heart J 149: 19-31, 2005.

WALSH PN: Platelet coagulation - protein interactions. Semin Thromb Hemost 30: 461-471, 2004.

WILCOX JN, SMITH KM, SCHWARTZ SM, GORDON D: Localization of tissue factor in the normal vessel wall and in the atherosclerotic plaque. Proc Natl Acad Sci USA 86: 2839-2843, 1989.

YIN X, YUTANI C, IKEDA Y, ENJYOJI K, ISHIBASHI-UEDA H, YASUDA S, TSAKUMOTO Y, NONOGI H, KANEDA Y, KATO H: Tissue factor pathway inhibitor gene delivery using HVJ-AVE liposomes markedly reduces restenosis in atherosclerotic arteries. Cardiovasc Res 56: 454-463, 2002.

ZHANG Y, DENG Y, LUTHER T, MULLER M, ZIEGLER R, WALDHERR R, STERN DM, NAVROTH PP: Tissue factor controls the balance of angiogenic and antiangiogenic properties of tumor cells in mice. J Clin Invest 94 : 1320-1327, 1994.

ZHANG Y, DENG Y, WENDT T, LILIENSIEK B, BIERHAUS A, GRETEN J, HE W, CHEN B, HACHWUNDERLE V, WALDHERR R, ZIEGLER R, MÄNNEL D, STERN DM, NEVROTH PP: Intravenous somatic gene transfer with antisense tissue factor restores blood flow by reducing tumor necrosis factorinduced tissue factor expression and fibrin deposition in mouse meth-A sarcoma. J Clin Invest 97: 2213-2224, 1996.

ZOLDHELYI P, CHEN ZQ, SHELAT HS, MCNATT JM, WILLERSON JT: Local gene transfer of tissue factor pathway inhibitor regulates intimal hyperplasia in atherosclerotic arteries. Proc Natl Acad Sci USA 98: 40784083, 2001.

\section{Corresponding author}

M. A. Malý, University Hospital Motol, Department of Cardiology, V Úvalu 84, 15006 Prague 5, Czech Republic. E-mail: martin.maly@email.cz 